\title{
Expression of MicroRNA-24 in Aflatoxin B1 Exposed Patients with Hepatocellular Carcinoma and Cirrhosis
}

\author{
Afaf M. Attia ${ }^{1}$, Dina Elhammady ${ }^{2}$, Maha R. Habeeb ${ }^{3}$, Neven F. Abbas ${ }^{3}$, \\ Maysaa El Sayed Zaki ${ }^{4}$
}

\begin{tabular}{|c|c|}
\hline & ABSTRACT \\
\hline $\begin{array}{l}\text { KEYWORDS } \\
\text { Aflatoxin B1, } \\
\text { Hepatocellular carcinoma, } \\
\text { Cirrhosis, } \\
\text { MicroRNA-24 }\end{array}$ & $\begin{array}{l}\text { This study aimed to assess the role of micro-ribonucleic acid-24 (microRNA-24) } \\
\text { expression in patients with cirrhosis and hepatocellular carcinoma (HCC) who have } \\
\text { experienced high levels of aflatoxin B1 (AFB1) exposure. Fifty HCC and } 24 \text { hepatic } \\
\text { cirrhosis patients, in addition to } 20 \text { healthy control subjects were included in this } \\
\text { study. Aflatoxin B1 was measured by enzyme-linked immunosorbent assay (ELISA) } \\
\text { and microRNA-24 was detected using real-time polymerase chain reaction (real-time } \\
\text { PCR). Both aflatoxin B1 levels and microRNA-24 expression were found to be } \\
\text { significantly increased in all patient groups in comparison to controls, more so in the } \\
\text { HCC than cirrhotic group (p<0.0001). A highly significant correlation was detected } \\
\text { between levels of AFB1 and amount of microRNA-24 expressed in both patient } \\
\text { groups relative to their control counterparts (p<0.0001). Receiver Operating } \\
\text { Characteristic (ROC) curve performed to evaluate the ability of microRNA-24 to } \\
\text { differentiate between HCC and cirrhosis showed that it had sensitivity of } 80 \% \text { and } \\
\text { specificity of } 63 \% \text { at cutoff } 1.3 \text {, which was highly significant (p<0.0001). Increased } \\
\text { aflatoxin B1 levels detected in patients with cirrhosis and HCC further support } \\
\text { previous studies evaluating the level of exposure of the Egyptian population to this } \\
\text { carcinogen and support the critical role of aflatoxin B1 in the appearance of HCC. In } \\
\text { addition, microRNA-24 expression levels demonstrated in both cirrhosis and HCC } \\
\text { might be valuable for use as a noninvasive diagnostic tool for diagnosis of HCC. }\end{array}$ \\
\hline
\end{tabular}

\section{Introduction}

Hepatocellular carcinoma is a potentially life-threatening affliction that constitutes over $90 \%$ of primary hepatic malignancy. This cancer is the sixth most common worldwide, accounting for a third of all cancer-related

\footnotetext{
${ }^{\overline{(I)} \text { Forensic Medicine and Clinical Toxicology }}$ Department, Faculty of Medicine, Mansoura University

(2) Tropical Medicine Department, Faculty of Medicine, Mansoura University

(3) Internal Medicine, Hepatology and Gastroenterology Department, Faculty of Medicine, Mansoura University

(4) Clinical Pathology Department, Faculty of Medicine, Mansoura University.
}

deaths (Jemal et al., 2011). Over $80 \%$ of HCC sufferers occur in developing countries most commonly as a result of exposure to hepatitis B or $\mathrm{C}$ viruses (HBV or $\mathrm{HCV}$ ) or ingestion of AFB1 that contaminate various crops, such as corn and peanuts, in hot humid climates. These two principal risk factors of $\mathrm{HCC}$ are predominantly found in highly endemic regions of Africa and Asia (Xia et al., 2013; Torre et al., 2015).

Several studies have demonstrated excessively high levels of aflatoxin exposure to the Egyptian community. AFB1 is the most common aflatoxin, originating from the Aspergillusflavus and Aspergillusparasiticus 
mold species (Hamid et al., 2013). Exaggerated concentrations of AFB1 have been detected in a number of cultivated food products, including wheat, corn, peanuts, fava beans, and both brown and white rise, from various urban and rural districts in Egypt (Hifnawy et al., 2004), while AFB1 was found in serum and urine of Egyptian infants with protein-energy malnutrition (Hatem et al., 2005).

From a pathogenic perspective, exposure to AFB1 promotes deoxyribonucleic acid (DNA) damage with generation of characteristic mutations in hepatic tissue, particularly with regard to the p53 tumor suppressor gene, a mutation found in over 50\% of AFB1- exposed HCC patients (Betaratinia et al., 2009). In addition, chronic infections with hepatitis $\mathrm{B}$ or $\mathrm{C}$ viruses cause liver damage with development of cirrhosis which, when coupled with the supplemental ability of hepatitis B viral DNA to integrate into the host genome, all contribute to an increased risk of development of HCC (Xiang et al., 2017).

Detection of HCC while in its initial stages is of paramount importance, as evidenced by a 5-year overall survival (OS) rate exceeding $50 \%$ when the disease is detected early compared to less than $10 \%$ with late $\mathrm{HCC}$ detection associated with poor prognosis as result of metastasis and recurrence (Hung et al., 2016). Therefore, therapeutic advances regarding $\mathrm{HCC}$ metastasis and recurrence are dependent on better comprehension of the elaborate molecular machinery determining disease aggression and evolution, as well as searching for important diagnostic markers and therapeutic targets (Liu et al., 2014).

Several studies have demonstrated a connection between HCC and the abnormal expression of microRNAs (Lyra-Gonzalez et al., 2015). MicroRNAs are short, endogenous, non-coding RNAs that coordinate the translation of protein-coding genes by either abolishing translation of target mRNAs or enhancing degradation of mRNA (Vera et al., 2013), thus regulating gene expression in a quick sensitive manner (Hayes and Chayama, 2016). MicroRNA disorganization has been implicated in a multitude of disorders, including cancer, through modification of natural cell development and differentiation (Lynam-Lennon et al., 2009).

The high stability of microRNAs in circulation, added to the fact that microRNA expression patterns appear to be tissue-specific, sets the stage for detection of circulating microRNAs to be potentially used as ideal biomarkers for pre-clinical HCC (Huang et al., 2016). Several studies have confirmed the ability of serum microRNAs to recognize early-stage HCC caused by infections with hepatitis B and $\mathrm{C}$ viruses (Motawi et al., 2015; Wang et al., 2015). However, very limited data exist correlating serum microRNA expression with HCC caused by AFB1 exposure. Therefore, analysis of microRNAs in circulation of patients with cirrhosis and HCC exposed to AFB1 may offer a clinically applicable non-invasive diagnostic means for detection of curable stages of this malignancy. Amid more than 2000 human microRNAs defined to date, microRNA-24 has been found to modulate the development of cancer in a variety of malignancies, including HCC (Hatziapostolou et al., 2011; Martin et al., 2014).

Therefore, we aimed in this study to assess the role of circulating microRNA-24 expression in patients with cirrhosis and those with HCC who have experienced high levels of AFB1 exposure, in addition to studying the role of AFB1 exposure as an associated risk factor for development of HCC. 


\section{Subjects and Methods}

This case-control study was conducted on 74 patients with hepatic cirrhosis due to hepatitis $\mathrm{C}$ virus (HCV) presented to Mansoura University Hospital during the period from January 2016 until March 2017. Of these, 50 patients had hepatocellular carcinoma and 24 patients were HCC free. In addition, 20 healthy subjects chosen from the blood donors' healthy subjects, were recruited as a control group.

Patients included in the study were those over 18 years of age who were positive for $\mathrm{HCV}$ antibodies with cirrhosis or $\mathrm{HCC}$ in absence of other known malignancies. Due to its established role as a direct participant in the hepato-carcinogenic process, and to avoid confounding results, patients with HBV were excluded, as were patients with human immunodeficiency virus (HIV). All patients were subjected to thorough clinical, laboratory, and radiological assessment. Cirrhotic patients were diagnosed based on imaging (ultrasound or computerized tomography) findings and characteristic liver function abnormalities, then classified according to Child-Pugh score.

In case of presence of elevated $\alpha$ fetoprotein $>400 \mathrm{ng} / \mathrm{ml}$, diagnosis of $\mathrm{HCC}$ was confirmed with one positive imaging study, such as magnetic resonance imaging (MRI) and/or computerized tomography (CT), while cases with normal $\alpha$-fetoprotein level required two positive imaging studies (Song and Bae, 2012)

\section{Blood Sampling}

Ten milliliters of blood were taken from each participant, which were then divided into three aliquots. One aliquot contained blood over ethylenediaminetetraacetic acid (EDTA) from which plasma was separated for microRNA-24 extraction, while another aliquot was a plain aliquot for sera separation for determination of aflatoxin B1 by immunoassay. Sera separated from the third aliquot were used for laboratory study of complete liver functions by autoanalyzer (Dialab 450 system), determination of circulatory anti-HCV by Elecys system (Roche-diagnostic) and alpha fetoprotein (AFP) measurement by ELISA DRG International Inc., USA.

\section{AFB1 measurement by ELISA}

"The aflatoxin B1 (AFB1) level in serum samples was determined by (Ridascreen- RBiopharm AG, Demstadt, Germany), an ELISA kit based on competitive enzyme immune assay for the quantitative analysis of aflatoxin B1. Preparation of serum samples required predilution with a dilution buffer" $(8.75 \mathrm{ml}$ sample buffer of Ridascreen and $1.25 \mathrm{ml}$ methanol).

\section{MicroRNA-24 assessment by real-time PCR MicroRNA isolation}

MicroRNA was prepared from $200 \mu 1$ serum samples by the use the microRNA extraction kit (Qiagen) according to the manufacturer's instructions. All isolated microRNAs were aliquoted and stored at $-80^{\circ} \mathrm{C}$ until use.

\section{Complementary DNA (cDNA) synthesis}

Reverse transcription (RT) was carried out in a $20 \mu \mathrm{l}$ solution that contained $0.2 \mu \mathrm{l}$ $200 \mathrm{U} / \mu \mathrm{l}$ reverse transcriptase (Qiagen), $0.2 \mu \mathrm{l}$ $40 \mathrm{U} / \mu \mathrm{l}$ ribonuclease inhibitor, $0.8 \mu \mathrm{l}$ $10 \mathrm{mmol} / \mathrm{ml} \mathrm{dNTP} \mathrm{mix,} 1.2 \mu 110 \mathrm{mmol} / \mathrm{ml} \mathrm{stem-}$ 
loop RT primer, $4 \mu \mathrm{l}$ RT buffer, $11.6 \mu \mathrm{l}$ RNAase-free water and $2 \mu \mathrm{l}$ microRNA template. After gentle mixing, the reaction mixtures were incubated at $25^{\circ} \mathrm{C}$ for $5 \mathrm{~min}$, $40^{\circ} \mathrm{C}$ for $60 \mathrm{~min}$ and then $70{ }^{\circ} \mathrm{C}$ for $15 \mathrm{~min}$. The final cDNA products were stored at $-20{ }^{\circ} \mathrm{C}$ until use. The reverse transcription primer was miR-24 [GenBank: AF480527.1],

5'-GTCGTATCCAGTGCGTGTCGTGGAGTCG GCAATTGCACTGATACGACCTGTTCCT-3'.

\section{Quantitative real-time PCR}

Real-time PCR was carried out following the manufacturer's protocol of SYBR Premix Ex Taq TM II reagents with $2 \mu \mathrm{l}$ cDNA template (Qiagen) (Fang et al., 2015).

\section{Statistical Analysis}

All statistical analyses were performed using statistical package for the social sciences (SPSS) 16.0 (Chicago, IL) and a significance threshold of $\mathrm{P}<0.05$ was used. Continuous data were expressed as mean \pm SD and compared between groups using Bonferroni test. Categorical data were analyzed using a twosided Chi-squared test or Fisher's exact test, when appropriately indicated. ROC curve was done to differentiate between groups.

\section{Ethical Approval}

Informed consent was taken from each patient. The research protocol was approved by the Ethical Committee of Faculty of Medicine, Mansoura University (proposal code: R.18.02.53).

\section{Results}

Demographic data and laboratory parameters of the studied groups are displayed in tables (1) and (2).

Different grading of cirrhosis and HCC patients is demonstrated in table (3). All patients were arranged according to Child-Pugh classification (Cholongitas et al, 2005). A large number of patients included in this study had decompensated liver disease and thus were given a Child class of $\mathrm{C}$ (14 cirrhotic and 20 HCC patients). Over half of HCC patients (30 patients; $60 \%$ ) suffered from a solitary HCC lesion, with the vast majority of patients $(72 \%)$ being staged as A and B (20 patients [40\%] and 16 patients [32\%], respectively) by the Barcelona Clinic Liver Cancer staging system (Llovet et al, 2003).

Aflatoxin B1 levels measured in study subjects are shown in table (4) and figure 1, and were shown to be significantly elevated in all patient groups of cirrhosis $(3.7 \pm 1.9)$ and HCC $(5.4 \pm 2.1)$ when compared to the control group (1.2 \pm 0.4$)$. Similarly, the increased AFB1 level was also found to be statistically significant in the HCC group in comparison to the group with cirrhosis $(\mathrm{p}<0.0001)$.

Evaluation of microRNA-24 expression in the different studied groups is demonstrated in table (5) and figure (2). MicroRNA-24 was found to be significantly higher in both HCC (2.6 \pm 1.3$)$ and cirrhotic $(1.7 \pm 1.3)$ patient groups when compared with controls $(0.6 \pm 0.3)$, with this elevation being more prominent in the HCC group than in cirrhotic patients, and in the cirrhotic group more than control individuals $(\mathrm{p}<0.0001)$. 
Correlation analysis between aflatoxin B1 and microRNA-24 expression in different studied groups showed no correlation between these parameters in the control group of subjects $(\mathrm{p}<0.755)$ (Figure 3$)$. However, highly significant correlation was found between the levels of aflatoxin B1 detected in cirrhotic patients and the amount of microRNA-24 expressed in these patients $(\mathrm{r}=0.933 ; \mathrm{p}<0.0001)$ (Figure 4), as was detected in HCC patients $(\mathrm{r}=0.868 ; \mathrm{p}<0.0001)$ (Figure 5).

ROC curve analysis for microRNA-24 expression demonstrated that at a cutoff of
0.85 , microRNA-24 had sensitivity of $80 \%$ and specificity of $75 \%$ in differentiating cirrhosis from normal liver of control group of subjects (Figure 6), and 98\% sensitivity and 85\% specificity in delineating HCC from control liver (Figure 7), both findings were highly significant $\quad(p<0.0001)$. Furthermore, when differentiating between patients with $\mathrm{HCC}$ and those with cirrhosis, microRNA-24 demonstrated sensitivity of $80 \%$ and specificity of $63 \%$ at a cutoff of 1.3 , another highly significant finding $(\mathrm{p}<0.0001)$ (Figure 8).

Table (1): Demographic data of the studied groups.

\begin{tabular}{|c|l|c|c|c|c|}
\hline \multicolumn{2}{|c|}{ Variable } & $\begin{array}{c}\text { Control } \\
(n=20)\end{array}$ & $\begin{array}{c}\text { Cirrhosis } \\
(n=24)\end{array}$ & $\begin{array}{c}\text { HCC } \\
(n=50)\end{array}$ & p value \\
\hline \multirow{2}{*}{$\begin{array}{c}\text { Age } \\
\text { (years) }\end{array}$} & Mean \pm SD & $49.1 \pm 5.2$ & $52.7 \pm 6.6$ & $50.2 \pm 5.3$ & \\
& Minimum & 32 & 40 & 32 & 0.08 \\
\multirow{2}{*}{ Sex } & Maximum & 58 & 65 & 60 & \\
\hline \multirow{2}{*}{ Smoking } & Males $(n)$ & 9 & 20 & 37 & $<0.01$ \\
& Females $(n)$ & 11 & 4 & 13 & $<0.01$ \\
\hline
\end{tabular}

HCC: Hepatocellular carcinoma, n: number 
Table (2): Laboratory parameters in the different studied groups.

\begin{tabular}{|l|c|c|c|c|}
\hline \multicolumn{1}{|c|}{ Variables } & $\begin{array}{c}\text { Control } \\
(n=20)\end{array}$ & $\begin{array}{c}\text { Cirrhosis } \\
(n=24)\end{array}$ & $\begin{array}{c}\text { HCC } \\
(n=50)\end{array}$ & p value \\
\hline WBC $\left(\times 10^{9} / \mathrm{L}\right)$ & $7.4 \pm 2.1$ & $4.4 \pm 1.5$ & $7.0 \pm 4.5$ & $<0.01^{*}$ \\
\hline RBC $\left(\times 10^{6} / \mu \mathrm{L}\right)$ & $3.5 \pm 0.4$ & $3.7 \pm 0.6$ & $4.4 \pm 0.8$ & $<0.001^{*}$ \\
\hline HB $(\mathrm{g} / \mathrm{L})$ & $13.4 \pm 0.8$ & $11.6 \pm 1.8$ & $12.7 \pm 2.4$ & $<0.05$ \\
\hline Platelets $\left(\times 10^{3} / \mu \mathrm{L}\right)$ & $243.4 \pm 89.2$ & $81.1 \pm 85.3$ & $155 \pm 38.1$ & $<0.0001^{*}$ \\
\hline INR & $1.2 \pm 0.2$ & $1.5 \pm 0.6$ & $1.1 \pm 0.4$ & $<0.0001^{*}$ \\
\hline Albumin (g/dL) & $3.9 \pm 0.5$ & $3.1 \pm 0.6$ & $3.7 \pm 0.5$ & $<0.0001^{*}$ \\
\hline Total bilirubin $(\mathrm{mg} / \mathrm{dL})$ & $0.8 \pm 0.1$ & $4.2 \pm 3.6$ & $1.3 \pm 1.3$ & $<0.0001^{*}$ \\
\hline Direct bilirubin $(\mathrm{mg} / \mathrm{dL})$ & $2.7 \pm 2.4$ & $2.7 \pm 2.4$ & $0.7 \pm 0.7$ & $<0.0001^{*}$ \\
\hline ALT $(\mathrm{U} / \mathrm{L})$ & $28.8 \pm 4.8$ & $42.1 \pm 17.9$ & $70.8 \pm 73.0$ & $<0.05^{*}$ \\
\hline AST $(\mathrm{U} / \mathrm{L})$ & $43.1 \pm 68.8$ & $63.1 \pm 19.9$ & $89.9 \pm 92.2$ & $<0.05^{*}$ \\
\hline Blood glucose $(\mathrm{mg} / \mathrm{dL})$ & $122.4 \pm 53.2$ & $124.7 \pm 47.2$ & $105.6 \pm 33.0$ & $<0.01^{*}$ \\
\hline Creatinine $(\mathrm{mg} / \mathrm{dL})$ & $0.9 \pm 0.2$ & $0.8 \pm 0.3$ & $0.8 \pm 0.2$ & $<0.01^{*}$ \\
\hline Na $(\mathrm{mEq} / \mathrm{L})$ & $136.7 \pm 3.2$ & $137.7 \pm 2.2$ & $138.2 \pm 4.3$ & $<0.01^{*}$ \\
\hline K $(\mathrm{mEq} / \mathrm{L})$ & $3.7 \pm 0.6$ & $3.9 \pm 0.4$ & $6.5 \pm 9.1$ & $<0.01^{*}$ \\
\hline AFP $(\mathrm{ng} / \mathrm{mL})$ & $8.1 \pm 3.4$ & $10.7 \pm 10.4$ & $104.1 \pm 114.9$ & $<0.0001^{*}$ \\
\hline
\end{tabular}

The $\mathrm{p}$ value indicates the statistical significance for the differences among groups. *Significant. WBC: White blood cells, RBC: Red blood cells, HB: Hemoglobin, INR: International normalized ratio, ALT: Alanine aminotransferase, AST: Aspartate aminotransferase, Na: Sodium, K: Potassium, AFP: Alfa-fetoprotein, n: number, HCC: Hepatocellular carcinoma.

Table (3): Different grading of the cirrhosis and HCC groups.

\begin{tabular}{|l|l|c|c|c|}
\hline \multicolumn{2}{|c|}{ Grading } & $\begin{array}{c}\text { Cirrhosis } \\
(\mathrm{n}=24)\end{array}$ & $\begin{array}{c}\text { HCC } \\
(\mathrm{n}=50)\end{array}$ & p value \\
\hline $\begin{array}{l}\text { Child-pugh } \\
\text { classification }\end{array}$ & A & 5 & 15 & \\
\hline Number of & B & 5 & 15 & 0.33 \\
masses & Single: n (\%) & & 20 & - \\
\hline & Multiple: $\mathrm{n}(\%)$ & & $30(60)$ & \\
BCLC & A: $\mathrm{n}(\%)$ & & $20(40)$ & - \\
& B: $\mathrm{n}(\%)$ & $16(40)$ & \\
& C: $\mathrm{n}(\%)$ & & $12(24)$ & $2(4)$ \\
\hline
\end{tabular}

The $\mathrm{p}$ value indicates the statistical significance for the differences among groups. ${ }^{*}$ Significant. HCC: Hepatocellular carcinoma, n: number, BCLC: Barcelona-Clınic Liver Cancer 
Table (4): Statistical analysis of aflatoxin B1 levels in the different studied groups.

\begin{tabular}{|l|c|c|c|}
\hline \multicolumn{1}{|c|}{$\begin{array}{c}\text { Aflatoxin B1 } \\
\text { (ppb) }\end{array}$} & $\begin{array}{c}\text { Control } \\
(n=20)\end{array}$ & $\begin{array}{c}\text { Cirrhosis } \\
(n=24)\end{array}$ & $\begin{array}{c}\text { HCC } \\
(n=50)\end{array}$ \\
\hline Mean SD & $1.2 \pm 0.4$ & $3.7 \pm 1.9$ & $5.4 \pm 2.1$ \\
Minimum & 0.5 & 1.5 & 2.5 \\
Maximum & 1.8 & 8 & 9 \\
\hline Bonferroni 1 & & $<0.001^{*}$ & $<0.001^{*}$ \\
\hline Bonferroni 2 & $<0.001^{*}$ & $<0.001^{*}$ & $<0.001^{*}$ \\
\hline Bonferroni 3 & $<0.001^{*}$ & & \\
\hline ANOVA & \multicolumn{3}{|c|}{$38.3(\mathrm{p}<0.0001)^{*}$} \\
\hline
\end{tabular}

Bonferroni 1: Comparison of control versus HCC and cirrhosis groups. Bonferroni 2: Comparison of HCC versus control and cirrhosis groups. Bonferroni 3: Comparison of cirrhosis versus control and HCC groups. ${ }^{*}$ Significant. ppb: Part per billion. ANOVA: Analysis of Variance, n: number, HCC: Hepatocellular carcinoma.

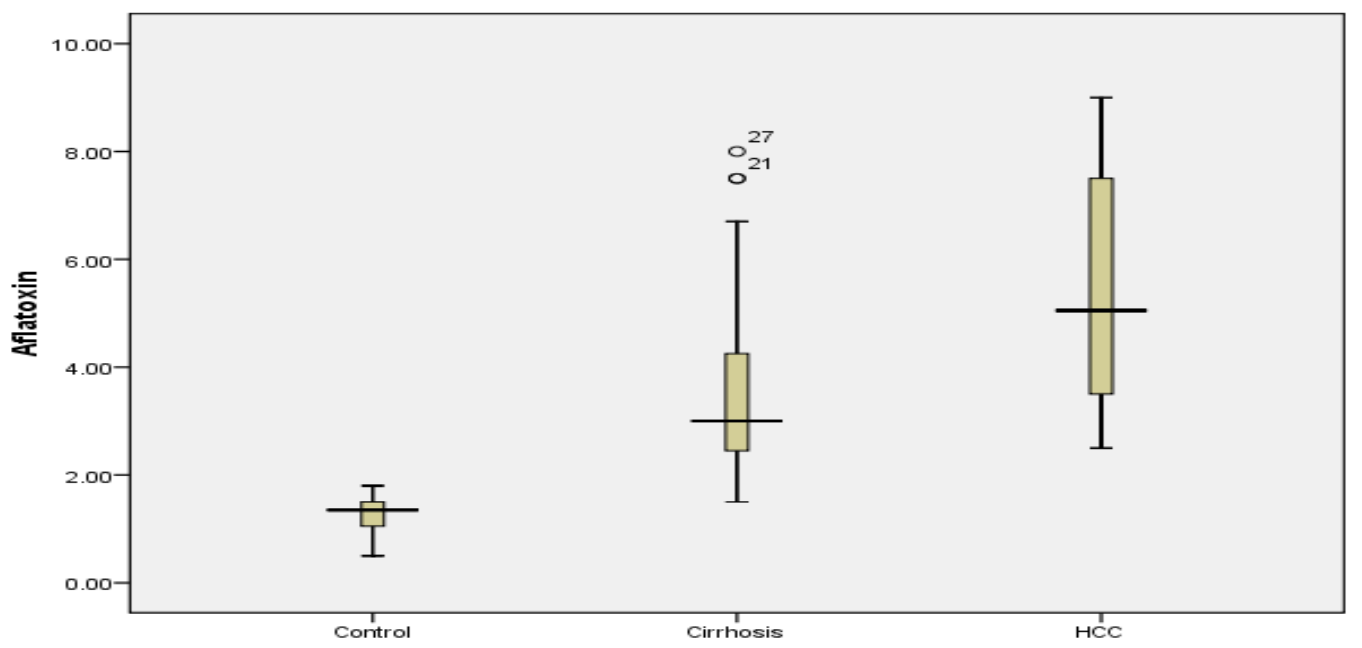

Fig. (1): Box plots for aflatoxin B1 levels in the different studied groups. HCC: Hepatocellular carcinoma

Table (5): Statistical analysis of microRNA-24 expression in the different studied groups.

\begin{tabular}{|l|c|c|c|}
\hline \multicolumn{1}{|c|}{ MicroRNA-24 } & $\begin{array}{c}\text { Control } \\
(n=20)\end{array}$ & $\begin{array}{c}\text { Cirrhosis } \\
(n=24)\end{array}$ & $\begin{array}{c}\text { HCC } \\
(n=50)\end{array}$ \\
\hline Mean + SD & $0.6 \pm 0.3$ & $1.7 \pm 1.3$ & $2.6 \pm 1.3$ \\
Minimum & 0.5 & 1.5 & 2.5 \\
Maximum & 1.8 & 8 & 9 \\
\hline Bonferroni 1 & $<0.001^{*}$ & $<0.01^{*}$ & $<0.001^{*}$ \\
\hline Bonferroni 2 & $<0.01^{*}$ & $<0.01^{*}$ & $<0.01^{*}$ \\
\hline Bonferroni 3 & \multicolumn{3}{|c|}{$20.9(\mathrm{p}<0.0001)^{*}$} \\
\hline ANOVA & \multicolumn{3}{|c|}{}
\end{tabular}

HCC: Hepatocellular carcinoma, RNA: ribonucleic acid, SD: Standard deviation, ANOVA: Analysis of Variance, $\mathrm{n}$ : number. Bonferroni 1: Comparison of control versus HCC and cirrhosis groups. Bonferroni 2: Comparison of HCC versus control and cirrhosis groups. Bonferroni 3: Comparison of cirrhosis versus control and HCC groups.*Significant. 


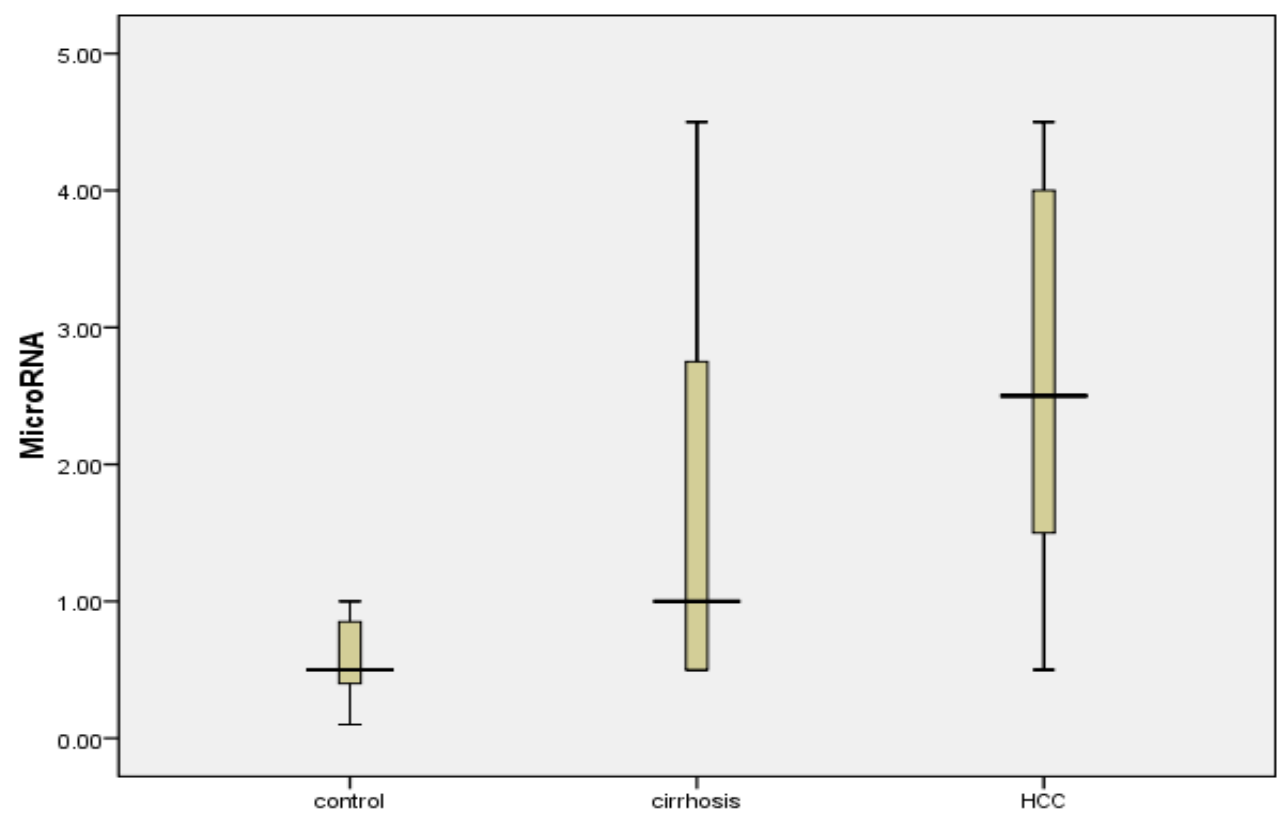

Fig. (2): Box plots for microRNA-24 expression in the different studied groups. RNA: ribonucleic acid.

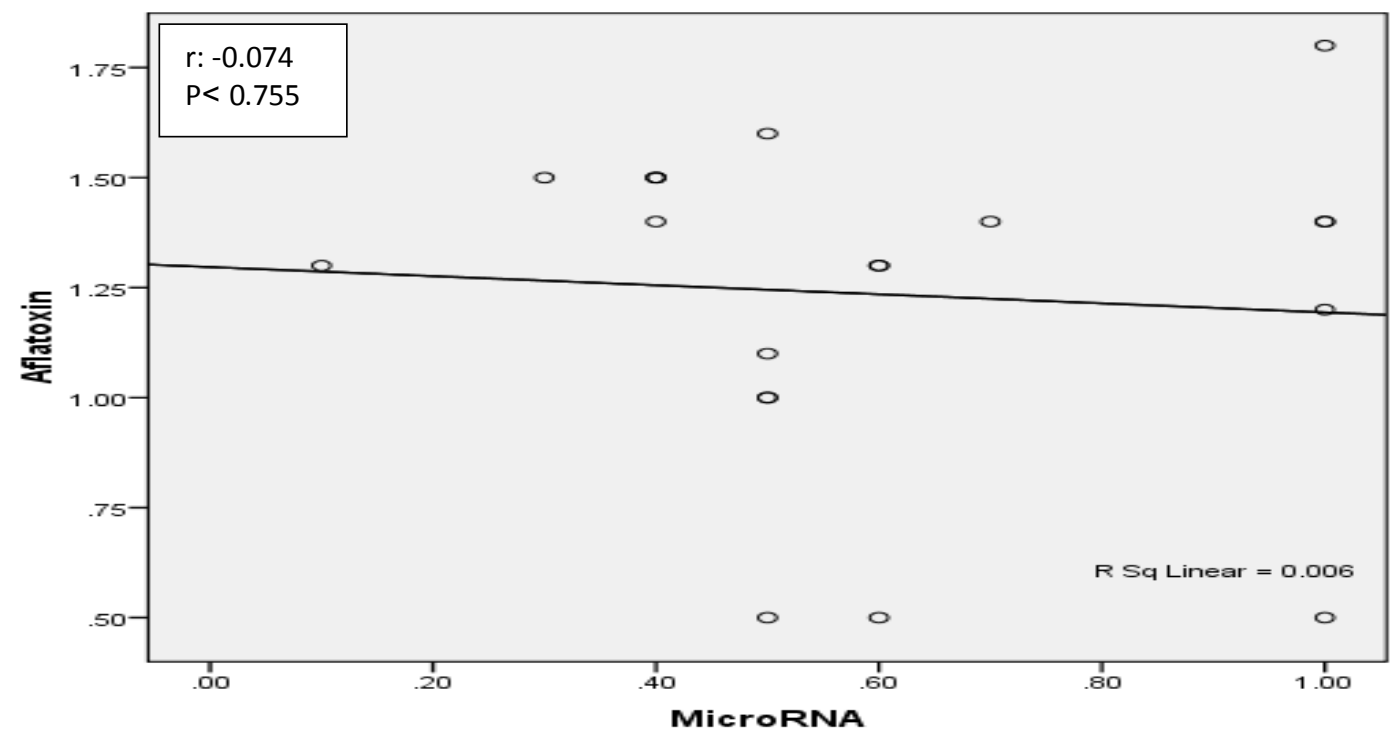

Fig. (3): Correlation between aflatoxin B1 level and microRNA-24 expression in control group. RNA: ribonucleic acid. 


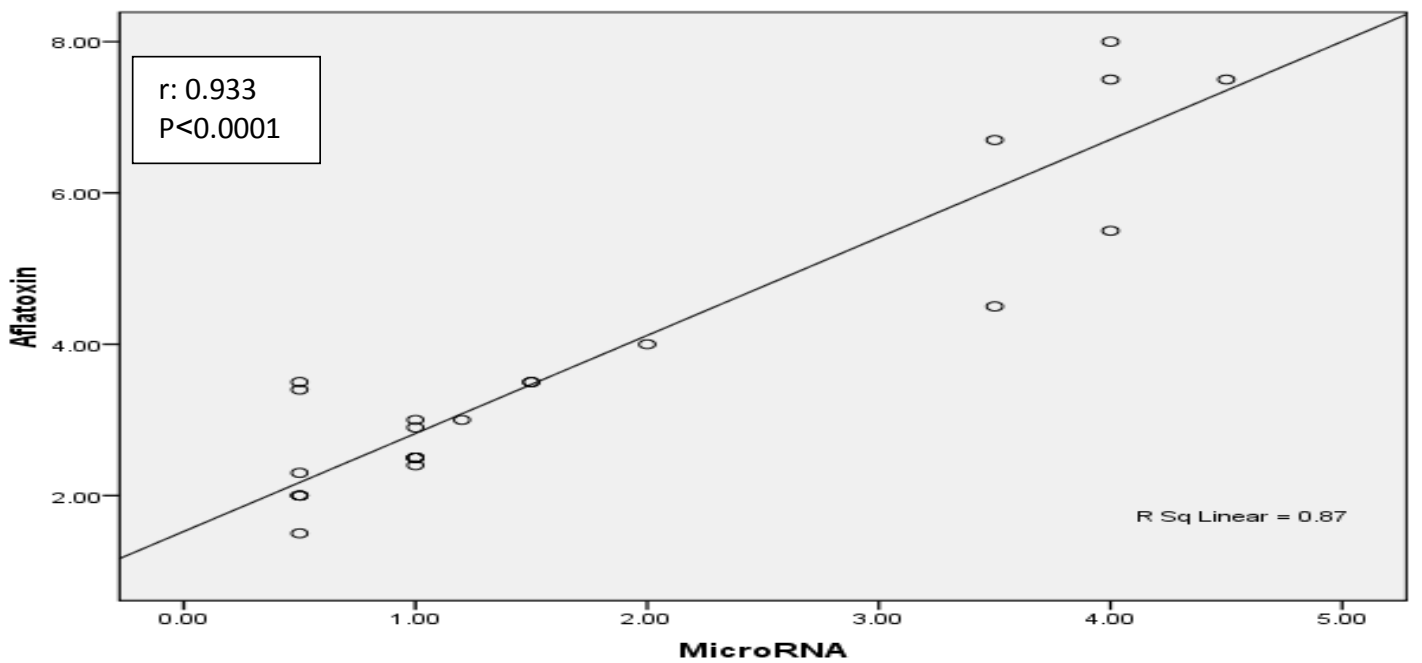

Fig. (4): Correlation between aflatoxin B1 level and microRNA-24 expression in cirrhosis group. RNA: ribonucleic acid.

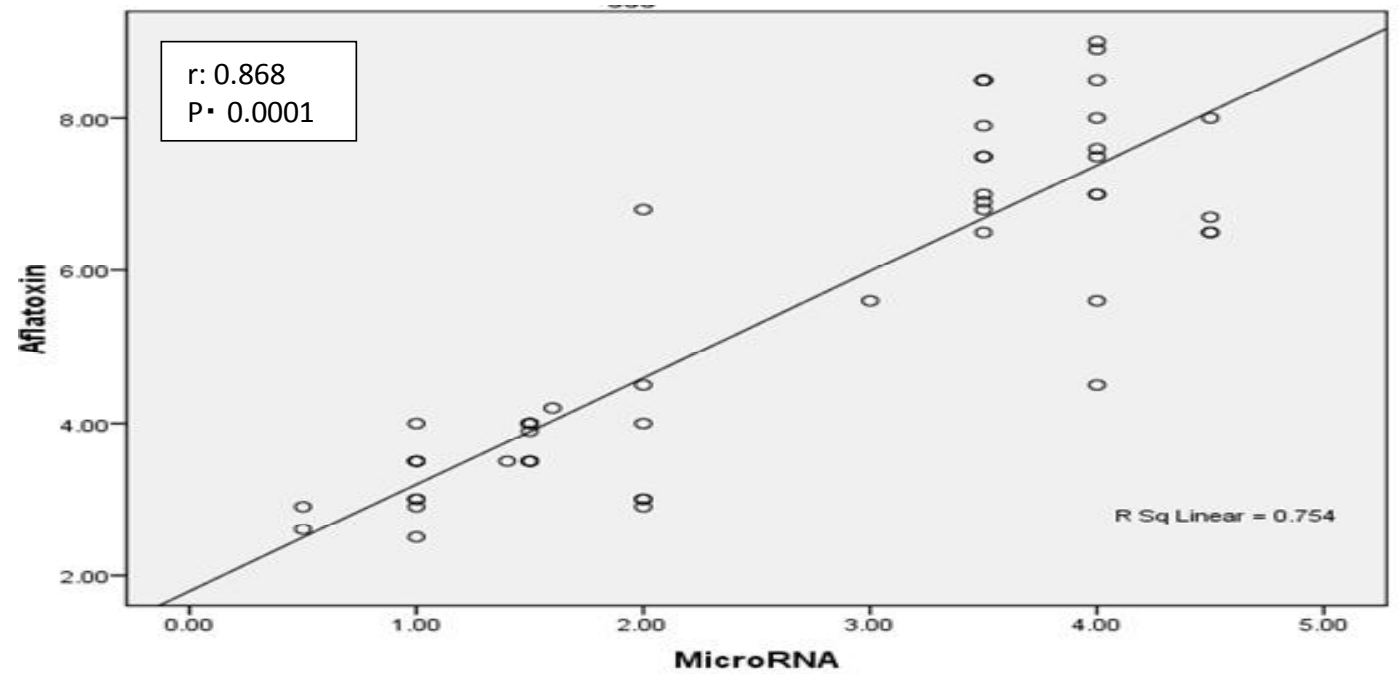

Fig. (5): Correlation between aflatoxin B1 level and microRNA expression in HCC group. RNA: ribonucleic acid, HCC: Hepatocellular carcinoma. 


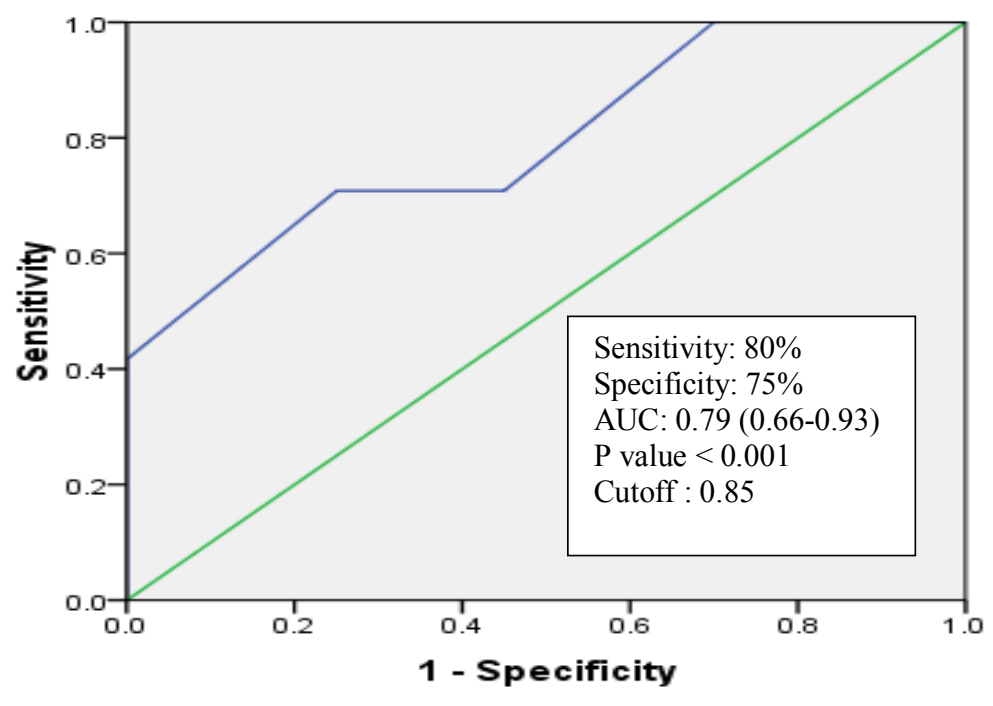

Fig. (6): The receiver operating characteristic (ROC) curve for microRNA-24 expression to differentiate cirrhosis from control group. ROC: receiver operating characteristic, RNA: ribonucleic acid, AUC: Area under the curve.

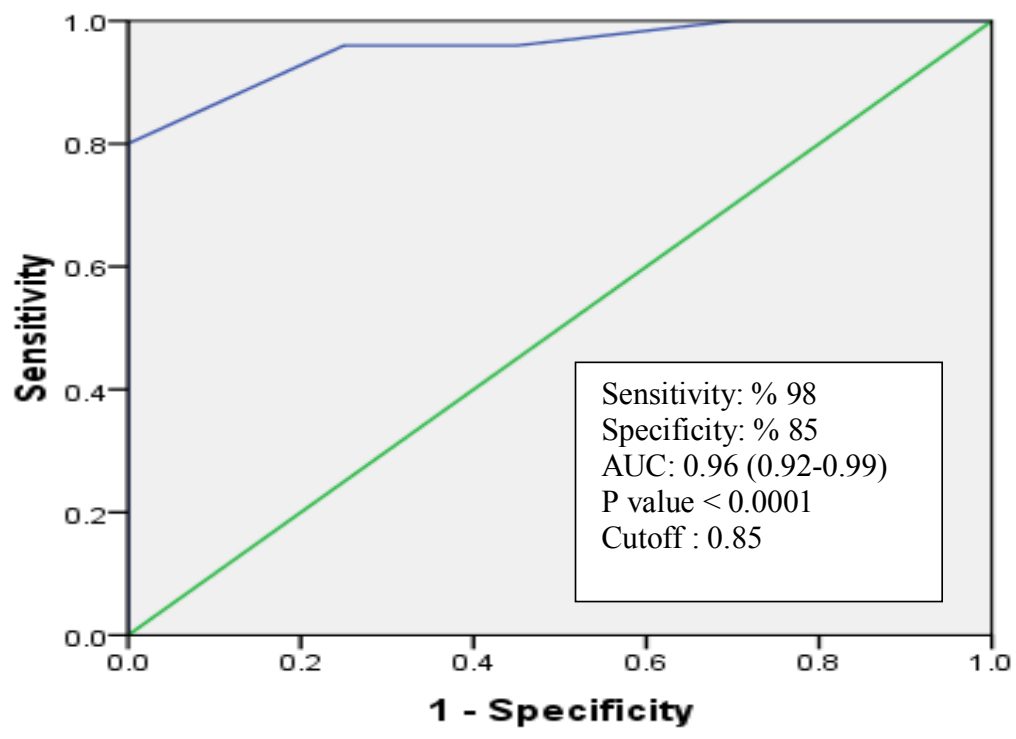

Fig. (7): The receiver operating characteristic (ROC) curve for microRNA-24 expression to differentiate HCC from control group. ROC: receiver operating characteristic, RNA: ribonucleic acid, AUC: Area under the curve, HCC: Hepatocellular carcinoma. 


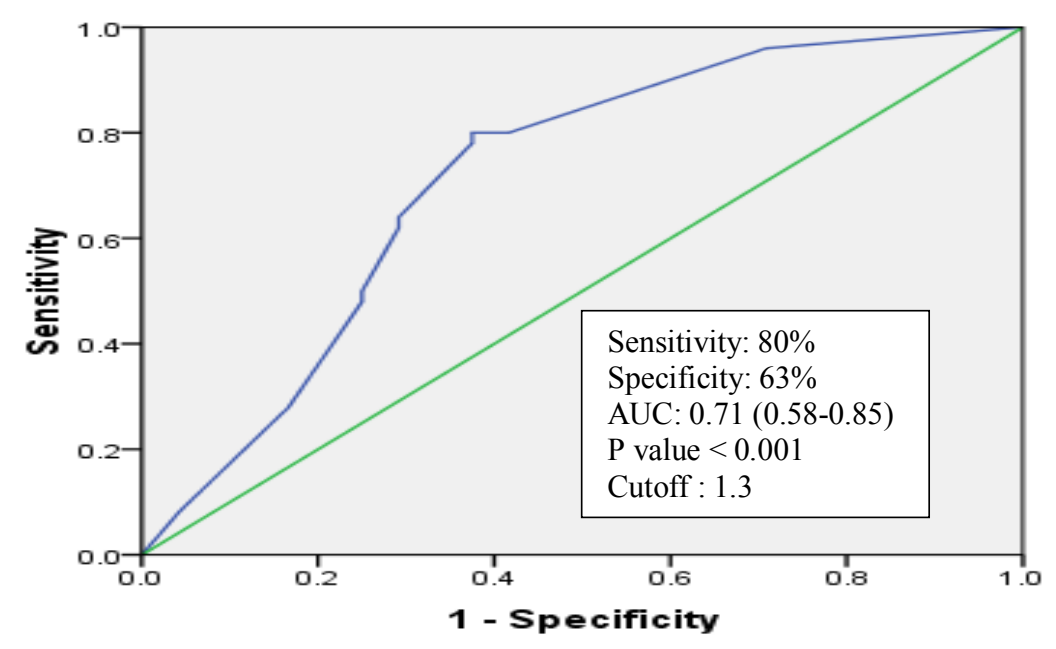

Fig. (8): The receiver operating characteristic (ROC) curve for microRNA-24 expression to differentiate HCC from cirrhosis group.ROC: receiver operating characteristic, RNA:ribonucleic acid, AUC: Area under the curve, HCC: Hepatocellular carcinoma.

\section{Discussion}

Ingestion of aflatoxins and exposure to hepatitis $\mathrm{B}$ or $\mathrm{C}$ viruses have been widely established as cardinal risk factors for hepatocarcinogenesis. Aflatoxin B1 (AFB1) is a mycotoxin that originates from some mold species such as Aspergillusparasiticus and Aspergillusflavus that commonly contaminate various harvested products when stored in moist environments. Ingestion of this toxin is followed by its metabolism by cytochrome $\mathrm{P} 450$ into aflatoxin B1-exo-8,9 epoxide (AFBO), a toxic metabolite capable of binding to DNA and causing genomic DNA damage, especially in the p53 suppressor gene, with initiation of hepatocellular carcinoma (HCC) development (Xia et al., 2013). In addition, the end stage of viral hepatitis caused by exposure to HBV or HCV is ultimately liver damage by cirrhosis which, in addition to integration into host genome by hepatitis B viral DNA, collectively contribute to an increased risk of development of HCC (Xiang et al., 2017).
The association of microRNAs with hepatocellular carcinoma has been a subject of intense analysis in recent years. By organizing gene expression, these small noncoding RNAs are capable of influencing a variety of different cell functions including cell differentiation and proliferation, metabolism, and cell apoptosis (Bartel, 2004). In addition, their effects on expression of oncogenes and tumor suppressor genes has established their pivotal role in pathogenesis of numerous cancers, including hepato-carcinogenesis (Ranganathan and Sivasankar, 2014; Lu et al., 2016). The exceptional stability and tissue-specific expression patterns of serum microRNAs have strengthened their role as potential contenders for noninvasive cancer testing (Wu et al., 2017). On this foundation, serum microRNAs have been proposed to be of potential diagnostic value for HCC, especially that related to high AFB1 exposure. Worthy of mention is the possible involvement of miRNA-24 in carcinogenesis (Han et al., 2012). Several studies have demonstrated persistent dysregulation of microRNA-24 in patients with hepatocellular carcinoma (Han et al., 2012; Salvi et al., 2013). 
Accordingly, the current case-control study aimed to assess and analyze the diagnostic role of circulating microRNA-24 expression in patients with $\mathrm{HCC}$ in comparison to patients with cirrhosis in areas of high AFB1 endemicity such as Egypt as well as to study the role of AFB1 exposure as an associated risk factor for development of HCC.

Aflatoxin B1 levels evaluated in 50 patients with $\mathrm{HCC}$ and 24 patients with hepatic cirrhosis included in this study was shown to be significantly elevated in all patient groups when compared to the control group of subjects. In addition, the increased AFB1 level was also found to be statistically significant in the HCC group in comparison to the group with cirrhosis. In similarity to the present study, Sharaf-Eldin et al. (2016) showed that serum aflatoxin levels were significantly increased to a greater extent in HCC patients than cirrhotic patients, and in the latter patients than in controls, possibly ascribed to the accumulative ramifications of prolonged exposure to aflatoxin with advanced age. These results corroborate analogous studies conducted in Egypt demonstrating higher aflatoxin B1 levels in cases of HCC, especially if they were male farmers from rural areas afflicted with chronic $\mathrm{HCV}$ and presenting with cirrhosis as well as multifocal HCC lesions. These results support the critical role of aflatoxin B1 in the appearance of HCC (Abdel-Wahab et al., 2008).

On a similar scale, evaluation of microRNA-24 expression in the different studied groups showed that microRNA-24 was found to be significantly higher in both HCC and cirrhotic patient groups when compared with controls, with this elevation being more prominent in the HCC group than in cirrhotic patients, and in the cirrhotic group more than control individuals. Frequent dysregulation of microRNA-24 expression in liver cancer has been previously demonstrated (Han et al., 2012; Salvi et al., 2013). In addition, various studies have exposed different expression patterns of serum microRNAs in HCCs when compared to non-HCCs ( $\mathrm{Wu}$ et al., 2017), highlighting the ability of serum microRNAs to distinguish HCC cases from controls (Motawi et al., 2015; Zhang et al., 2015; Hung et al., 2016). Taken together, results of these studies propose that serum microRNAs might be of relevance as noninvasive biomarkers for the diagnosis of HCC.

Therefore, in an attempt to determine the efficacy of microRNA-24 expression in discriminating between $\mathrm{HCC}$, cirrhosis, and control subjects, ROC curve was done for all studied groups. At a cutoff of 0.85 , microRNA24 was found to adequately differentiate cirrhosis from controls with sensitivity of $80 \%$ and specificity of $75 \%$, while an even higher sensitivity of $98 \%$ and specificity of $85 \%$ was demonstrated in discerning $\mathrm{HCC}$ from control individuals, both findings being highly significant. Moreover, microRNA-24 was found to differentiate HCC from cirrhosis at a cutoff of 1.3 with sensitivity of $80 \%$ and specificity of $63 \%$, also a highly significant finding. Our data indicate that the overexpression of microRNA24 detected in both our study groups of cirrhosis and HCC might be of use as a noninvasive biomarker delineating cirrhosis from HCC.

Correlation between aflatoxin B1 levels and serum microRNA-24 expression in the current study was insignificant in the control group of study subjects, while both patient groups showed highly significant correlation between these studied variables, more so in HCC patients than in cirrhotic patients. A study by Liu et al. (2014) showed that increased expression of microRNA-24 could advance AFB1-DNA synthesis, possibly as a result of their targeted effect on detoxification enzyme genes (Oda et al., 2012) resulting in diminished detoxification capacity with consequent aggregation of AFB1- 
DNA (Liu et al., 2014). Furthermore, other studies showed that low microRNA expression of DNA repair would limit the scope of DNA repair thus increasing the extent of DNA damage and risk of HCC (Long et al., 2013; Huang et al., 2016). These observations contribute to a unique understanding of the mechanism behind AFB1-induced HCC (Liu et al., 2014).

In conclusion, our results show that increased aflatoxin B1 levels detected in patients with cirrhosis and HCC further support previous studies evaluating the level of exposure of the Egyptian population to this carcinogen and support the critical role of aflatoxin B1 in the appearance of HCC. In addition, microRNA-24 expression levels demonstrated in both cirrhosis and HCC might be valuable for use as a noninvasive diagnostic tool for diagnosis of HCC. However, further studies into the fundamental role of microRNAs and their dysregulated expression patterns involved in hepatic carcinogenesis will afford valuable insights into the intricate molecular pathogenesis of HCC with possible facilitation of novel therapies for HCC patients, particularly those from areas of high AFB1 exposure.

\section{References}

Abdel-Wahab, M.; Mostafa, M.; Sabry, M.; et al. (2008): "Aflatoxins as a risk factor for hepatocellular carcinoma in Egypt, Mansoura Gastroenterology Center study". Hepatogastroenterology, 55:1754-1759.

Bartel, D.P. (2004): "MicroRNAs: genomics, biogenesis, mechanism, and function". Cell, 116 (2):281-297.

Besaratinia, A.; Kim, S.I.; Hainaut, P. and Pfeifer, G.P. (2009): "In vitro recapitulating of TP53 mutagenesis in hepatocellular carcinoma associated with dietary aflatoxin B1 exposure". Gastroenterology, 137:1127-1137.

Cholongitas, E.; Papatheodoridis, G.V.; Vangeli, M.; et al. (2005): "Systematic review: The model for end-stage liver disease-should it replace Child-Pugh's classification for assessing prognosis in cirrhosis?" Alimentary Pharmacology \& Therapeutics, 22 (11-12): 1079-1089.

Fang, Z.; Tang, J.; Bai, Y.; et al. (2015): "Plasma levels of microRNA-24, microRNA-320a, and microRNA-423-5p are potential biomarkers for colorectal carcinoma". J. Exp. Clin. Cancer Res., $34: 86-88$.

Hamid, A.S.; Tesfamariam, I.G.; Zhang, Y. and Zhang, Z.G. (2013): "Aflatoxin B1induced hepatocellular carcinoma in developing countries: geographical distribution, mechanism of action and prevention". Oncol. Lett., 5:1087-1092.

Han, Z.B.; Zhong, L.; Teng, M.J.; et al. (2012): "Identification of recurrencerelated microRNAs in hepatocellular carcinoma following liver transplantation". Mol. Oncol., 6: 445-457.

Hatem, N.L.; Hassab, H.M.A.; Abd AlRahman, E.M. and El-Sayed, R.L. (2005): "Prevalence of aflatoxins in blood and urine of Egyptian infants with proteinenergy malnutrition". Food and Nutrition Bulletin, 26 (1):49-56.

Hatziapostolou, M.; Polytarchou, C.; Aggelidou, E.; et al.(2011): "An HNF4 $\alpha$ miRNA inflammatory feedback circuit regulates hepatocellular oncogenesis". Cell, 147(6):1233-1247.

Hayes, N. and Chayama, K. (2016): "MicroRNAs as biomarkers for liver 
disease and hepatocellular carcinoma". Int. J. Mol. Sci., 17:280284.

Hifnawy, M.S.; Mangoud, A.M.; Eissa, M.H.; et al. (2004): "The role of aflatoxin-contaminated food materials and $\mathrm{HCV}$ in developing hepatocellular carcinoma in Al- Sharkia Governorate, Egypt". J. Egypt Soc. Parasitol., 34 (1 Suppl): $479-488$.

Huang, J.T.; Liu, S.M.; Ma, H.; et al. (2016): "Systematic review and metaanalysis: circulating miRNAs for diagnosis of hepatocellular carcinoma". J. Cell Physiol., 231: 328-335.

Hung, C.H.; Hu, T.H.; Lu, S.N.; et al. (2016): "Circulating microRNAs as biomarkers for diagnosis of early hepatocellular carcinoma associated with hepatitis B virus". Int. J. Cancer, 138: 714-720.

Jemal, A.; Bray, F.; Center, M.M.; et al. (2011): "Global cancer statistics". C.A. Cancer J. Clin., 61:69-90.

Liu, Y.X.; Long, X.D.; Xi, Z.F.; et al. (2014): "MicroRNA-24 modulates aflatoxin b1-related hepatocellular carcinoma prognosis and tumorigenesis". Bio Med. Research International, 2014: ID 482926.

Liovet, J.M.; Burroughs, A. and Bruix, J. (2003): "Hepatocellular carcinoma". Lancet, 362:1907-1917.

Long, X.D.; Zhao, D.; Wang, C.; et al. (2013): "Genetic polymorphisms in DNA repair genes XRCC4 and XRCC5 and aflatoxin B1-related hepatocellular carcinoma". Epidemiology, 24:671-681.

Lu, Y.L.; Yao, J.G.; Huang, X.Y.; et al. (2016): "Prognostic significance of miR-1268a expression and its beneficial effects for post-operative adjuvant transarterial chemoembolization in hepatocellular carcinoma". Sci. Rep., 6: 36104-36115.

Lynam-Lennon, N.; Maher, S.G. and Reynolds, J.V. (2009): "The roles of microRNA in cancer and apoptosis". Biological Reviews, 84(1):5571.

Lyra-Gonzalez, I.; Flores-Fong, L.E.; Gonzalez-Garcia, I.; et al. (2015): "MicroRNAs dysregulation in hepatocellular carcinoma: Insights in genomic medicine". World J. Hepatol., 7: 15301540 .

Martin, E.C.; Elliott, S.; Rhodes, L.V.; et al. (2014): "Preferential star strand biogenesis of pre-miR-24-2 targets PKC-alpha and suppresses cell survival in MCF-7 breast cancer cells". Mol. Carcinog., 53:38-48.

Motawi, T.K.; Shaker, O.G.; El-Maraghy, S.A. and Senousy, M.A. (2015): "Serum MicroRNAs as potential biomarkers for early diagnosis of hepatitis c virus-related hepatocellular carcinoma in Egyptian patients". PLoS One, 10: e0137706.

Oda, Y.; Nakajima, M.; Mohri, T.; et al. (2012): "Aryl hydrocarbon receptor nuclear translocator in human liver is regulated by miR-24". Toxicol. Appl. Pharmacol., 260:222-231.

Ranganathan, K. and Sivasankar, V. (2014): "MicroRNAs-Biology and clinical applications". J. Oral Maxillofac. Pathol., 18: 229-234.

Salvi, A.; Abeni, E.; Portolani, N.; Barlati, S. and De Petro, G. (2013): "Human hepatocellular carcinoma cell-specific miRNAs reveal the differential expression of miR-24 and miR-27a in cirrhotic/noncirrhotic HCC". International Journal of Oncology, 42(2):391-402. 
Sharaf-Eldin, M.; Salah, R.; Soliman, H.H.; et al. (2016): "Aflatoxin as an environmental risk factor attributable to liver cancer in Nile Delta". Indian Journal of Medical Research and Pharmaceutical Sciences, 3(4), 19-26.

Song, D.S. and Bae, S.H. (2012): "Changes of guidelines diagnosing hepatocellular carcinoma during the last ten-year period". Clinical and Molecular Hepatology, 18(3): 258-267.

Torre, L.A.; Bray, F.; Siegel, R.L.; et al. (2015): "Global cancer statistics, 2012". C.A. Cancer J.Clin., 65: 87-108.

Vera, J.; Lai, X.; Schmitz, U. and Wolkenhauer, O. (2013): "MicroRNAregulated networks: the perfect storm for classical molecular biology, the ideal scenario for systems biology". Advances in Experimental Medicine and Biology, 774:55-76.

Wang, Y.; Gao, Y.; Shi, W.; et al. (2015): "Profiles of differential expression of circulating microRNAs in hepatitis B virus-positive small hepatocellular carcinoma". Cancer Biomark., 15: 171180.

Wu, X.M.; Xi, Z.F.; Liao, P.; et al. (2017): "Diagnostic and prognostic potential of serum microRNA-4651 for patients with hepato- cellular carcinoma related to aflatoxin B1". Oncotarget, 8 (46): 8123581249.

Xia, Q.; Huang, X.Y.; Xue, F.; et al. (2013): Genetic polymorphisms of DNA repair genes and DNA repair capacity related to aflatoxin b1 (AFB1)-induced DNA damages, In: New Research Directions in DNA Repair. Chen, C. (Ed.), Rijeka: InTech, P.P. 377-412.

Xiang, X.; Qin, H.G.; You, X.M.; et al. (2017): "Expression of P62 with hepatocellular carcinoma involving hepatitis B virus infection and aflatoxin B1 exposure". Cancer Med., 6:2357-2369.

Zhang, Y.C.; Xu, Z.; Zhang, T.F. and Wang, Y.L. (2015): "Circulating microRNAs as diagnostic and prognostic tools for hepatocellular carcinoma". World J. Gastroenterol., 21: 9853-9862. 


\section{ظهور الحامض النووي الريبوزي_ع الدقيق في مرضى سرطان خلايا الكبد

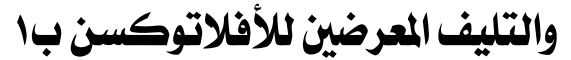

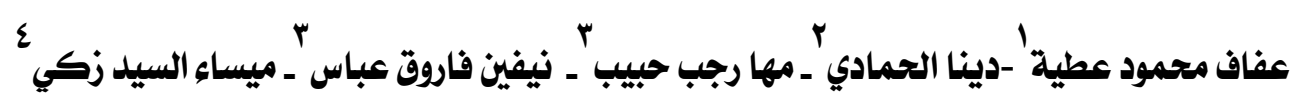

'قسم الطب الثرعي والسموم الإكلينيكية ـ كلية الطب - جامعة المنصورة

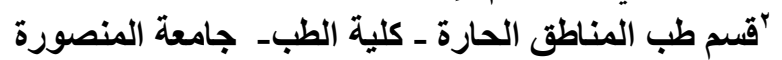

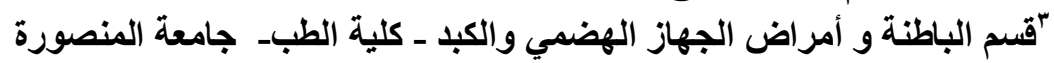

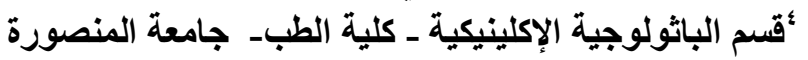

استهدفت هذه الدر اسـة تقيبم دور الحامض النووي الريبوزي_ع ب الدقيق في المرضى الذين بعانون من

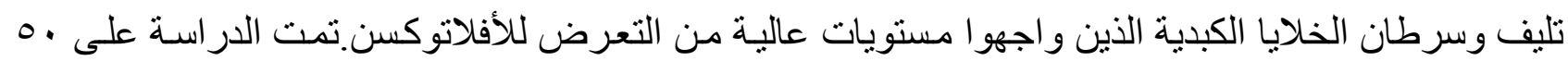

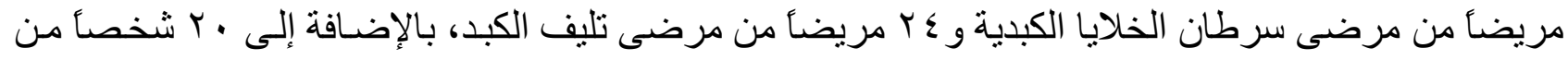
الأشخاص الأصحاء كمجمو عة ضابطة في هذه الدر اسـة. وتم قياس الأفلاتوكسن بواسطة جهاز فحص الإنزيم

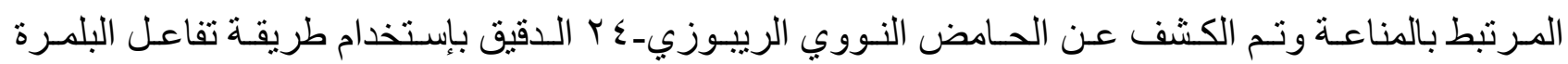
المتسلسل. وقد أظهرت النتائج أن مستويات الأفلاتوكسين وظهور الحامض النووي الريبوزي-ع ب الدقيق كانت في زيادة كبيرة في جميع مجموعات المرضى مقارنة مع المجموعة الضابطة، وفي مجموعة السرطان الكبدي وطي

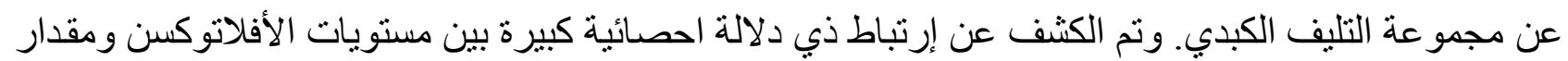

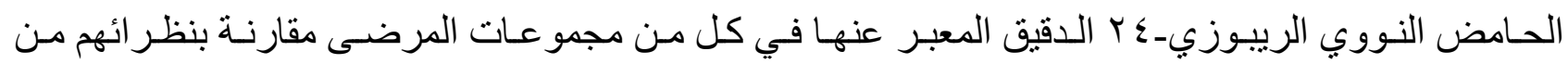

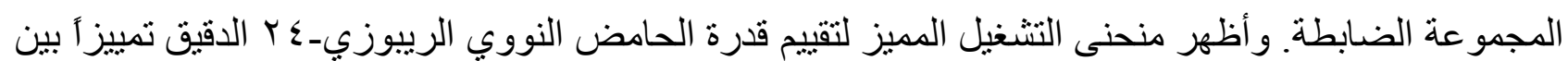

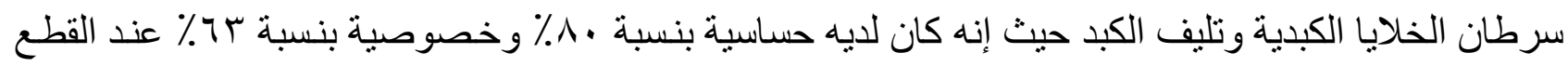
r, ا ـو الخلاصة أن زيادة مستويات الأفلاتوكسن المكتشفة في المرضى الذين يعانون من التليف الكبدي وسرطان الخلايا الكبدية تدعم الدر اسات السابقة التي تقيم مستوى تعرض السكان المصريين لهذه المـادة المسرطنة وتداندم

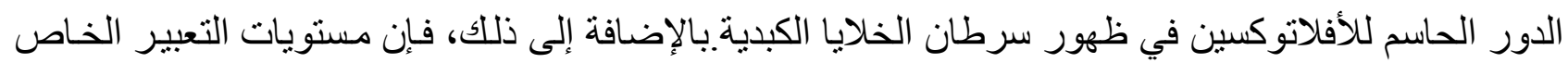
بالحامض النووي الريبوزي_ع ب الدقيق الظاهرة في كل من تليف الكبد وسرطان الخلايـا الكبديـة قد تكون ذات قيمة لإستخدامها كأداة تشخيص غير تداخليه لتشخيص سرطئ طان الخلايا الكبدية. 